\title{
Corporate social responsibility, organisational reputation and liability of foreignness
}

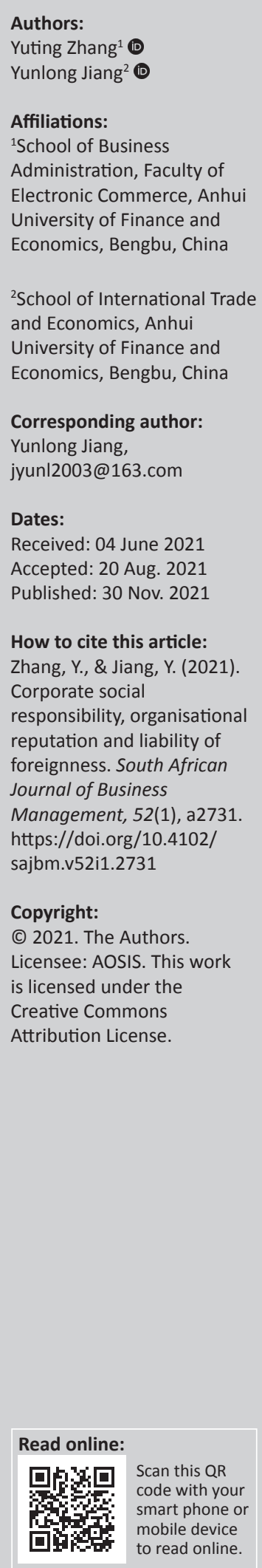

Purpose: This study aimed to test the impact of corporate social responsibility (CSR) and its subdivision dimensions on the liability of foreignness (LOF), as well as the mediating effect of organisational reputation.

Methodology: A total of 301 observations from 43 branches and subsidiaries of China's four major banks in 23 host countries from 2012 to 2018 were selected as samples to examine the impact of CSR and its segmented dimensions on the LOF. The mediating role of the parent company's organisational reputation in the relationship between CSR and LOF was also examined. After controlling for the possible influence of firm age, firm size, economic distance, regulatory distance, and cultural distance on the model, three regression models were built.

Findings: Liability of foreignness can be reduced by increasing CSR; and increasing technical CSR is especially effective in this regard. Organisational reputation plays a mediating role in the relationship between CSR and LOF.

Practical Implications: Fulfilling CSR can help reduce the LOF.

Originality: This research comprehensively explains the different views of current scholars on CSR and enriches the existing research on overcoming the LOF from the perspective of nonmarket mechanisms. It also provides new insight into the mediating effect of organisational reputation on CSR and its indirect effect on the LOF.

Keywords: corporate social responsibility; organisational reputation; liability of foreignness; going global, regression models, organisational reputation; China; banking.

\section{Introduction}

According to a report from the McKinsey Global Institute, by the end of 2019, nearly half of all Fortune 500 companies were in Asia. This includes about 120 from China, which has made great progress in its continuous integration into the world economy by pursuing its going global strategy, which is the global expansion of China-based companies. However, compared to the Standard \& Poor's (S\&P) 500 average of $44 \%$, Chinese companies earn less than $20 \%$ of their revenues from overseas operations, leaving substantial scope for further international growth. Zaheer (1995) found that in comparison to local companies on the London and Tokyo stock exchanges, foreign enterprises achieved lower average revenues and profits, and termed this phenomenon the liability of foreignness (LOF). This liability arises from the lack of a market system, cultural-, social-, and business-practice differences, and deficient understandings of the host country. Thus, foreign enterprises face increased costs or reduced benefits through circumstances and processes that affect their international operations - eventually resulting in low performance - making it difficult to survive in the host country market. Consequently, ways to overcome the LOF have become the focus of extensive attention in business and academic circles as an important issue that multinational corporations (MNCs) must resolve in their pursuit of international growth (Zhang, Wang, \& Jiang, 2016).

Concerning the factors affecting the LOF (Chen, Griffith, \& Hu, 2006; Kostova, 1997; Madhok \& Keyhani, 2012) and overcoming mechanisms (Klossek, Linke, \& Nippa, 2012; Kostiva \& Zaheer, 1999; Petersen \& Pedersen, 2002), existing studies have thoroughly analysed the entry mode (Du, Shi, \& Cai, 2016; Eden \& Miller, 2004; Klossek, 2012; Yuan, 2019), location selection (Gomes, Carneiro, \& Dib, 2018), and isomorphism (Kostiva \& Zaheer, 1999; Salomon \& Wu, 2012; Zhang \& Wang, 2015) of market-based mechanisms, based on resource-based view and strategic management theory. The extant research has laid a solid foundation for further research on LOF. A review of literature, however, indicates a dearth of studies that discuss the mechanisms for overcoming the LOF from the perspective of corporate social responsibility (CSR) - a non-market 
mechanism. Based on the new institutional theory, Marano, Tashman and Kostova (2017) discuss the relationship between CSR disclosure and the liability of origin from the perspective of MNCs in emerging markets, indicating that CSR disclosure is an effective means to overcome the liability of origin. Differences remain, however, between the liability of origin and the LOF. The liability of origin emphasises institutional gaps at a national level, while the LOF focuses on unfavourable management conditions at the firm level. By building and maintaining a relationship with stakeholders and improving the reputation of the organisation, the social responsibility (SR) of the foreign subsidiary can be conducive to the formation of a good corporate image that is more easily recognisable by local consumers. Therefore, CSR can be considered a non-market-oriented way to contribute socially to helping subsidiaries rapidly overcome entry barriers and gain recognition from market stakeholders in the host country (Campbell, Eden, \& Miller, 2012).

Corporate social responsibility may also have a positive impact on LOF (Huang, Duan, \& Zhu, 2017) because it entails financial contributions towards social responsibilities, which reduces corporate performance and further aggravates the LOF faced by subsidiaries. Here, two questions require answering: (1) What is the relationship between CSR and LOF? and (2) What are the contingency factors behind these seemingly inconsistent effects? Two key aspects are evident from a review of literature.

First, we explore the composition of CSR. Most existing studies use a wholistic or single CSR index (Entine, 2003) in their analyses, ignoring CSR's multidimensional structural characteristics (Bouslah, Kryzanowski, \& M'Zali, 2013). Freeman, Harrison and Wicks (2008) divided stakeholders into two categories: primary and secondary. Primary stakeholders are those who play a key role in the operations of the enterprise, while secondary stakeholders have influence over the decisions of primary stakeholders. Mattingly and Berman (2006) believed that because of varied perspectives on CSR activities, market participants view the motivation of enterprises in performing CSR differently, while the differentiation in the components of CSR exerts specific influences on market activities. These can be divided into technical CSR for major stakeholders and institutional CSR for minor stakeholders. Given the possible differences in the impact of each subdivision, it is necessary to explore the impact of CSR both as a whole and by analysing the effects of its components on the LOF.

Second, we explore the contingency factors affecting the relationship between CSR and LOF. Li and Zhang (2010) indicated that consumers' evaluations of enterprises and their products are closely related to organisational reputation. Enterprises influence consumers' purchase intention by fulfilling their social responsibilities and by building their reputation through enhancing their public image. Thus, CSR can affect the LOF directly or indirectly by building the reputation of the parent company.
Based on the work by Mattingly and Berman (2006), this study divides CSR into technical and institutional CSR - according to the stakeholder and LOF theories - by selecting China's going global banking branches or subsidiary companies as samples; combining these with sample enterprise data from 2012 to 2018; discussing the effects of CSR and its components on the LOF; and establishing the mediation effect of parent organisation reputation between CSR and their LOF.

This study supplements the existing body of literature in numerous ways. First, we discuss the impact of CSR and its components on the LOF. Shareholders, supply chain stakeholders, and employees are classified as the main stakeholders of the enterprises that undertake technical CSR. Secondary stakeholders of the enterprise are classified by behaviours related to environmental and public-utility philanthropy and are defined as institutional CSR. We also discuss the influence of technical and institutional CSR on the LOF, to establish the core differences in the direction and degree of influence. This research comprehensively explains the different views of current scholars on CSR and enriches the existing research on overcoming the LOF from the perspective of non-market mechanisms.

Second, we explore the mediating effect of organisational reputation on CSR and its indirect effect on the LOF. Organisational reputation can be regarded as a valuable intangible asset, actively fulfilling the SR of the foreign subsidiary. It gains the recognition of the local stakeholders in the host country, and establishes positive organisational reputation of the parent company, overcoming the LOF. When a subsidiary is confronted with a crisis or events that create a negative perspective, the positive organisational reputation of the parent company can assist in efficiently overcoming the crisis while eliminating the impact of the negative events. Therefore, the parent company's organisational reputation plays a mediating role between CSR and the LOF.

\section{Literature review and hypothesis development \\ Corporate social responsibility and liability of foreignness}

The LOF is one of the main reasons why subsidiaries do not operate well in the host market, thereby resulting in reduced performance. Eden and Miller (2004) believed that unfamiliar risk, discriminatory risk, and relational risk are the main driving factors of LOF, in combination with the three pillars of institutional distance. Against the backdrop of economic globalisation, taking SR is not only a necessary task to qualify as a corporate citizen, but it is also an important way for an enterprise to gain new competitive advantages (Porter, 2006). To some extent, multinational subsidiaries can overcome the LOF by fulfilling their social responsibilities (Marano et al., 2017), which is demonstrated by:

- First, fulfilling shareholder responsibility and SR, which enhances the acceptability of products, promotes sales, and provides returns to shareholders. It can also help 
enterprises to understand the demand preferences of the local market and thus, accumulate operational experience to reduce the LOF posed by unfamiliar risks. Similar to the conclusion of Benlemlih and Girerd-Potin (2014), enterprises' active responsibility to shareholders can improve the risk perception level of enterprises and reduce the risks.

- Second, fulfilling supply chain and environmental responsibilities. This conveys to the host government and the main audience (consumers) that the enterprise is trustworthy, thereby avoiding the influence of ethnocentrism of the host country's local consumers to foreignness, and reducing the LOF caused by risks arising from discrimination. Godfrey (2005) showed that the enterprise can reduce transaction costs effectively by fulfilling corresponding responsibilities and establishing trust with suppliers. Benlemlih and Girerd-Potin (2014) indicated that enterprises' active commitment to customer responsibility can help them build customer loyalty and reduce the cost of relationship maintenance. All these costs help reduce the LOF.

- Third, fulfilling employee responsibilities. This assists in the coordination of the internal and external uncertainties of the enterprise, mitigates the adverse effects of cultural distance (CD), and lowers the administrative or management costs, ultimately reducing the LOF caused by relational risk. Bauer, Derwall and Hann (2009) believed that enterprises' active responsibility to employees can slow down the fluctuations of future cash flow effectively, ease employee relations, enhance employees' loyalty to the company, and in turn, improve the productivity and innovation ability of enterprises. Verwijmeren and Derwall (2010) showed that a firm's good performance in human resources can slow down its default risk, thus improving its credit rating and reducing its risk. Bouslah et al. (2013) further found that the good employee relations in enterprises was negatively correlated with the level of volatility of stock returns and idiotype risks. Based on the above analysis, we propose the following hypothesis:

$\mathrm{H}_{1}$ : Fulfilling their CSR will assist subsidiaries in reducing their LOF.

As a result of the complexity of CSR, the academic community has not yet formed a unified classification system; however, many scholars have tried to study the dimension division of CSR from different perspectives. Scholars have studied from the perspective of society as a whole (Carroll, 1991), the practicality of accountability subjects, the nature of business and stakeholders (Freeman et al., 2008; Mattingly \& Berman, 2006); discussing the dimension division of CSR from multiple perspectives. Among these scholars, the stakeholder perspective is widely recognised and accepted. Freeman et al. (2008) distinguished stakeholders into primary and secondary stakeholders. The former refers to stakeholders who are critical to the operation of the business, while the latter represents those who can influence the main stakeholders of the company. Of course, CSR activities are different for different types of stakeholders. After an exploratory factor analysis on the KLD database, Mattingly and Berman (2006) classified CSR activities into technical CSR that serves primary stakeholders, and institutional CSR for secondary stakeholders. They believed that there is no essential difference between CSR activities, however, because of the different audiences of the activities, market participants have different views on the motivation of enterprises to fulfil SR. Chen, Ioannou, and Serafeim (2014) indicated that fulfilling social responsibilities with key stakeholders, such as customers, employees, and business partners would reduce agency and transaction costs effectively and contribute to increasing the revenue and profit of enterprises.

Therefore, on the one hand, technical CSR is mainly targeted at the responsibilities of shareholders, employees, and supply chains, and is often considered to be the result of the exchange of capital within an enterprise because of its operating conditions (Godfrey, Merrill, \& Hansen, 2009). Therefore, undertaking technical CSR can maintain a sound cooperative relationship with major stakeholders, improve corporate performance, and reduce the LOF. On the other hand, institutional CSR enhances the development of the enterprise by influencing the decisions of the major stakeholders, while serving the minor stakeholders by fulfilling their environmental, community, and public charity responsibilities. Thus, the demonstration of non-utilitarian actions is beneficial in building a responsible corporate image of the enterprise. Mattingly and Berman (2006) believed that institutional CSR was less likely to be regarded as the purely self-interested behaviour of managers for the purpose of profit, and more likely to be regarded as voluntary social charity behaviour based on norms or realistic demands, thus providing evidence of 'selfless' motivation for corporate managers. Therefore, institutional CSR can be accepted by the broad audience as well, and can form a relatively stable social network that reduces the influence of LOF. Based on the above analysis, we propose the following hypotheses:

$\mathrm{H}_{1 \mathrm{a}}$ : Subsidiaries can reduce the LOF by fulfilling their technical CSR.

$\mathbf{H}_{1 \mathrm{~b}}$ : Subsidiaries can reduce the LOF by fulfilling their institutional CSR.

\section{Corporate social responsibility and reputation of parent company}

Organisational reputation is predominantly considered as a social structure, as supported by the consensus of most studies and academic discourses on business management (Barnett, Jermier, \& Lafferty, 2006). Organisational reputation is the overall cognition and emotional evaluation of an enterprise's past behaviour (Neville, Bell, \& Menguc, 2005). It is a tangible asset that is difficult to acquire, replace, or (for competitors) imitate. It may affect perceived organisational efficiency (Mitchell, 2015) and resource attraction (Padanyi \& Gainer, 2003) that contribute to the formation of the competitive advantages of enterprises. 
Research on the impact of CSR on organisational reputation can be broadly divided into two categories. The first approach is to take CSR as a whole and discuss its impact on the organisation's reputation, as investigated by Brammer and Pavelin (2004). From their study of 227 listed companies in the UK, they concluded that correct CSR strategy formulation helps to build a corporate reputation. Lai, Chiu, Yang, \& Pai, (2010) found that CSR and corporate reputation have a positive impact on brand equity and brand performance by discussing this from a consumer perspective. Mitra (2011) pointed out that the construction of strategic CSR would help firms obtain additional business benefits based on the case analysis of Tata Motors in India. Eberle and Li (2013) found that the interactivity of online media can improve communication about CSR, thereby improving the reputation of enterprises. Odriozola and Baraibar-Diez (2017), based on the analysis of listed Spanish companies, pointed out that undertaking CSR has a positive impact on corporate reputation.

The second approach is to analyse the impact of CSR on the reputation of the organisation from a single or specific subdivided dimension. Williams and Barrett (2000) argued that charitable donations by enterprises reduce the risk of reputation loss and facilitate a higher evaluation of their reputation. Huo and Zhou (2014), through an investigation of 194 sample enterprises, found that corporate responsibility in the economic, legal, charitable, and employee spheres has a positive impact on corporate reputation. Zeng, Zhang and Wang (2017) found that CSR performance, after being divided into market-, social-, and environmental responsibility management, is positively correlated with corporate reputation. Based on the data of 320 listed companies in the United States (US), Melo and Garrido-Morgado (2012) built a model to evaluate corporate reputation, discussed the impact of multidimensional constructs of CSR on corporate reputation, and found that the industry sector played a significant role. From the perspective of CSR as a whole or by each subdivision, an enterprise is more likely to be accepted by the internal and external market environment when it undertakes SR (Wen \& Fang, 2008). It is likely to be regarded by stakeholders as an enterprise that can promote employment and local economic development (Bhattacharya \& Sen, 2004), is honest and trustworthy in providing quality products (Hasseldine, Salama, \& Toms, 2005; Wang, Tian, \& Yang, 2012), is willing to participate in environmental protection or charitable donations (Cai, Cui, \& Jo, 2016), and responsible in its approach towards the public and society. Similarly, a multinational subsidiary that actively meets its SR contributes to its development in the host market and contributes to the construction and maintenance of the parent company's organisational reputation. Thus, we posit:

$\mathrm{H}_{2}$ : Corporate CSR of a multinational subsidiary helps to improve the organisational reputation of the parent company.

$\mathbf{H}_{2 \mathrm{a}}$ : A multinational subsidiary can enhance the organisational reputation of the parent company by fulfilling the technical CSR.
$\mathrm{H}_{2 \mathrm{~b}}$ : A multinational subsidiary can increase the organisational reputation of the parent company by fulfilling the institutional CSR.

\section{Mediating effect of parent company's organisational reputation}

Organisational reputation is based on evaluations or perceptions generated by the past behaviour of the organisation, and refers to the needs and expectations of stakeholders that the organisation needs to meet in the future (Mo \& Wang, 2012). An enterprise that actively undertakes SR will often leave a good impression on stakeholders, thus enhancing the attractiveness of its products to consumers. Existing studies have discussed the mediating role of organisational reputation in the relationship between CSR and customer perceptions and loyalty. For example, Neville et al. (2005) showed that organisational reputation contributes to the formation of consumers' attitudes and perceptions positive perceptions promote consumers' purchasing behaviour and establish positive brand association. Li and Zhang (2010) constructed a conceptual model of the impact of CSR on corporate reputation and customer loyalty and noted that corporate reputation is the mediating variable in the relationship between CSR and customer loyalty; CSR affects customer satisfaction through corporate reputation, which fosters customer loyalty. Some studies have analysed the mediating role of organisational reputation between CSR and the organisation's position in the market network. For example, Maignon and Ferrell (2004) indicated that the fulfilment of SR enhances corporate reputation. A strong corporate reputation is conducive to the formation of cordial relationships between enterprises and investors, leading to the further expansion of the relationship network. Peloza and Shang (2011) noted that corporate reputation plays an intermediary role between CSR and organisational performance, whereby CSR can change an enterprise's position in the market network.

Transnational subsidiaries can gain recognition from stakeholders by undertaking CSR, which is conducive to the formation of a sound organisational reputation for the parent company. As for technical CSR, actively executing responsibilities facilitates the efficient building of strong trust relationships with major stakeholders (Pant \& Ramachandran, 2017), effectively reducing transaction and other agency costs, and establishing positive judgement of subsidiaries and their parent companies in the host country market (Doh, Howton, Howton, \& Siegel, 2009). The nonutilitarian characteristics of institutional CSR increase the likelihood of winning the favour and acceptance of its audience, thereby enhancing the trust of consumers in the parent enterprise. The sound organisational reputation of the parent company also helps the subsidiary to win the favour of the host country's government - benefitting from supportive policies or preferential treatment - to further improve the effectiveness of SR (Yoon, Gurhan-Canli, \& Schwarz, 2006) and alleviate the possible negative impact of a crisis on the subsidiary (Zhou \& Wang, 2020), this helps the subsidiary to overcome the LOF. Thus, we propose: 
$\mathbf{H}_{3}$ : A parent company's organisational reputation plays a mediating role between CSR and the LOF.

$\mathbf{H}_{3 \mathrm{a}}$ : Parent organisation's reputation mediates the relationship between technical CSR and the LOF.

$\mathbf{H}_{3 \mathrm{~b}}$ : The parent company's organisational reputation plays a mediating role in the relationship between institutional CSR and LOF.

\section{Methodology Sample selection}

To test the impact of CSR and the parent company's organisational reputation on the LOF, 43 foreign branches or subsidiaries of the Industrial and Commercial Bank of China (ICBC), Agricultural Bank of China (ABC), China Construction Bank (CCB), and Bank of China (BOC) were selected as samples in this study. A total of 301 observational values of sample enterprises from 2012 to 2018 were selected for empirical analysis. Sample enterprises were mainly distributed in 23 countries or regions, such as: Argentina, Australia, Brazil, Britain, Canada, Taiwan, Hong Kong, Hungary, Indonesia, Kazakhstan, India, Macau, Malaysia, New Zealand, Russia, Vietnam, Cambodia, Thailand, Zambia, Luxembourg, Germany, US, and Panama. The underlying data for these firms were obtained from the Global Bank and Financial Analysis Database (BankFocus). The database provides operational and credit analysis data for more than 44000 leading global banks and major financial institutions and organisations. It is regarded as the most authoritative analysis library for the global banking industry. The data used in this study are licensed by the database.

The basis of our sample selection are as follows: First, because the banking industry is greatly influenced by the institutional environment of the host country, it constitutes a highly suitable representative sample for studying LOF. Second, China has, in recent years, vigorously advocated the ability of enterprise operations to go global, as represented by the four major banks in their industry, whose foreign branches or subsidiaries were selected. According to the 2019 Fortune Global 500 Bank Profit list, by the end of 2018, the total assets of ICBC reached 27.6 trillion yuan, ranking first in the global banking industry, $\mathrm{CCB}$ ranked second with total assets of 23.2 trillion yuan, $\mathrm{ABC}$ ranked third with 22.6 trillion yuan, and BOC ranked fourth with 21.2 trillion yuan. Given the domestic market share of the Big Four state-owned banks, this is generalisable to China's banking industry. Third, the timeframe is limited to 2012-2018, because of the availability of sample data.

\section{Variable measurement}

\section{Dependent variable}

In the existing studies, the measurement of the LOF is not uniform and variables can be broadly divided into two categories. First, is the adoption of direct indicators, such as performance, $\mathrm{X}$-efficiency, and exit rate. An alternative is the selection proxy variables, such as geographical distance and institutional distance. This study argues that when measuring the LOF, we should not only consider the identity of foreignness but also compare it with local examples. Therefore, referencing the method of Nachum (2003), the ratio of the performance of the sample banks to the average performance of major local banks is adopted to measure the LOF. The performance of sample enterprises and local banks is measured by return on equity (ROE). In addition, the LOF is a negative indicator - there is an inverse relationship between variables and indicators. Increased firm performance results in reduced LOF, which is treated with a negative sign according to the method used by $\mathrm{Du}$ et al. (2016). This is calculated as:

$\mathrm{LOF}=P_{f} /\left(\Sigma_{n} P_{l} / n\right)$

[Eqn 1]

where, $P_{f}$ is the performance of foreign subsidiaries, $P_{1}$ denotes the performance of major local banks, and $n$ indicates the number of major local banks.

\section{Independent variable}

The overall data on CSR comes from HeXun.com. This site currently provides information regarding the global financial market, covering basic data, including stocks, funds, foreign exchange, futures, bonds, and banks. The specific weight allocations of different industries are different. Mattingly and Berman (2006), who conducted an exploratory factor analysis on the Kinder, Lydenberg, and Domini (KLD) database, found that CSR activities are not inherently different, but market participants hold different views on the motivations for CSR behaviour. The main stakeholders pay more attention to the exchange behaviour in line with corporate interests, while secondary stakeholders pay more attention to the voluntary social charity behaviour based on realistic demands.

This study follows Mattingly and Berman (2006) in applying the characteristics of the research object, selecting the average value of shareholders', employees', and supply chain-related responsibility as indicators of technical CSR, while selecting the average value of environmental and $\mathrm{SH}$ from HeXun.com as indicators of institutional CSR.

\section{Mediating variables}

To measure organisational reputation, some studies use questionnaires through scale development, while others use proxy variables. Considering that media reports are an important source of information for stakeholders to evaluate organisational reputation, this study adopts the methods of Kuo and Chen (2013) and measures the tendency of the news media to report on an enterprise as an index of the organisational reputation of the parent company. First, through the Authorized Database of Important Chinese Newspapers from China National Knowledge Infrastructure (CNKI), relevant media reports on the parent company are collected. The reporting frequency of each media report is manually coded. Positive reports are assigned 1, negative reports are assigned -1 , and neutral reports are assigned 0 . The final score of the parent 
company's organisational reputation is calculated by referring to the Janis-Fadner formula:

$\mathrm{OR}=\left\{\begin{array}{l}\frac{e^{2}-e c}{t^{2}} e>c \\ \frac{e c-e^{2}}{t^{2}} e<c \\ 0 e=c\end{array}\right\}$

where, $e$ and $c$ represent the number of positive and negative reports, respectively, $t$ represent the total number of reports, such that $\mathrm{t}=e+c$.

\section{Control variables}

The control variables are considered at the firm and country levels. For the firm-level control variables, firm age and firm size are selected. Firm age is calculated using the operating time of the subsidiary in the host country until 2018, and firm size is measured by the annual total assets of the subsidiary. The control variables at the national level are economic distance (ED), regulatory distance (RD), and $\mathrm{CD}$ between the home and host country. The ED is calculated by the annual difference between the sum of the economic freedom index of the host country and China. The RD is calculated by the difference between the host country and China in the global governance index annually. Based on the traditional Hofstede Center six-dimensional index, CD is supplemented by the reciprocal diplomatic relations between countries and China until 2018 to compensate for the shortcomings of the CD index in terms of time dynamics. The formula of Kogut and Singh (1988) used to calculate the CD index is detailed as:

$$
C D_{f}=\Sigma_{n=1}^{6}\left[\left(I_{n f}-I_{n c}\right)^{2} / V_{n}\right] / 6+1 / t
$$

where, $I_{n f}$ is the index value of country $\mathrm{f}$ in the $n^{\text {th }}$ dimension, $I_{n c}$ is the index value of China in the $n^{\text {th }}$ dimension, $V \mathrm{n}$ is the variance of the $n^{\text {th }}$ dimension, and $t$ represents the duration of the establishment of diplomatic relations between each country and China by 2018 .

\section{Data sourcing}

The basic data of the sample firms were from the BankFocus database, and the data related to CSR were from HeXun. com. The data on ED were from the annual report released by the Heritage Foundation and the Wall Street Journal. The data on RD were from The Global Governance Index of The World Bank, whereas CD was from the Hofstede Centre. Finally, the date of the establishment of diplomatic ties between the two countries was from the official website of the Ministry of Foreign Affairs of the People's Republic of China. It should be noted that for the total assets data of sample firms, some samples had inconsistent statistical units, and the data were processed by exchange rate conversion. The exchange rate data of various countries were from the official website of the State Administration of Foreign Exchange. A small number of missing values were omitted accordingly.

\section{Empirical analysis Model building}

The branches and subsidiaries of China's four major global banks from 2012 to 2018 were selected as samples to examine the impact of CSR and its segmented dimensions on the LOF, as well as the mediating role of the parent company's organisational reputation in the relationship between CSR and LOF. Since performance indicators have a certain lag when they are used to measure the LOF, the first-order lag term of the explained variables was also introduced into the model. After controlling for the possible influence of firm age, firm size, ED, RD, and CD on the model, regression models (1), (2), and (3) were built:

$$
\begin{aligned}
& \mathrm{LOF}=\alpha_{0}+\alpha_{1} \mathrm{~L} \cdot \mathrm{LOF}+\alpha_{2} \mathrm{CSR}+\text { Control }+\varepsilon \\
& \mathrm{OR}=\beta_{0}+\beta_{1} \mathrm{CSR}+\text { Control }+\varepsilon \\
& \mathrm{LOF}=\lambda_{0}+\lambda_{1} \mathrm{~L} \cdot \mathrm{LOF}+\lambda_{2} \mathrm{CSR}+\lambda_{3} \mathrm{OR}+\text { Control }+\varepsilon
\end{aligned}
$$

From the above equations, the liability of foreignness, L.LOF lagging behind the first-order LOF, CSR represents the corporate social responsibility and its component dimensions, OR represents the parent organisation reputation, $\alpha, \beta$, and $\lambda$ are coefficients, Control indicates control variables; and $\varepsilon$ the random disturbance terms.

\section{Regression results}

Based on our theoretical elaboration and model construction, this study uses Stata 15.0 software to test the influence of independent variables on dependent variables. The mediating effect of the parent company's organisational reputation is tested based on the three-step method used by Wen, Zhang, Hou and Liu (2004). The descriptive statistics and correlation analysis of the variables are shown in Table 1.

\section{Results}

\section{The impact of corporate social responsibility and subdivided dimensions on liability of foreignness}

To test the impact of CSR on the LOF, the variables are initially processed centrally. When considering the LOF, the performance index measurement has a certain lag, which belongs to dynamic panel data. Therefore, the systematic generalized method of moments (GMM) method is adopted to carry out the corresponding regression analysis. The specific test results are shown in Table 2.

In Table 2, Model 0 is the initial model that contains only control variables. In Models 1-3, the coefficient of the first-order lag term (L.LOF) of LOF is significantly positive, indicating that the LOF does have some continuity. The $p$-values of AR(1) in all models are less than 0.05 , those of $\mathrm{AR}(2)$ are all greater than 0.05 , and the $p$-values of Hansen are all greater than 0.05 , indicating that the model meets the requirements of instrumental variables and that the setting is reasonable. 
TABLE 1: Descriptive statistics and correlation analysis of variables.

\begin{tabular}{|c|c|c|c|c|c|c|c|c|c|c|c|c|c|}
\hline Variable & Mean & Min & Max & LOF & CSR & TCSR & ICSR & OR & AGE & SIZE & ED & $C D$ & RD \\
\hline LOF & -1.07 & -61.1 & 12.90 & 1.00 & - & - & - & - & - & - & - & - & - \\
\hline CSR & 3.84 & 3.48 & 4.44 & -0.01 & 1.00 & - & - & - & - & - & - & - & - \\
\hline TCSR & 1.92 & 1.44 & 2.85 & -0.01 & 0.99 & 1.00 & - & - & - & - & - & - & - \\
\hline ICSR & 1.648 & 1.13 & 2.63 & -0.01 & 0.99 & 0.98 & 1.00 & - & - & - & - & - & - \\
\hline OR & 0.21 & 0.01 & 0.72 & -0.13 & -0.31 & -0.28 & -0.31 & 1.00 & - & - & - & - & - \\
\hline AGE & 2.87 & 0.00 & 4.67 & 0.023 & -0.13 & -0.11 & -0.13 & 0.02 & 1.00 & - & - & - & - \\
\hline SIZE & 16.06 & 1.62 & 24.05 & -0.11 & -0.14 & -0.14 & -0.15 & 0.06 & 0.55 & 1.000 & - & - & - \\
\hline ED & 18.02 & 0.10 & 38.80 & -0.02 & 0.10 & 0.09 & 0.09 & -0.02 & 0.04 & 0.29 & 1.00 & - & - \\
\hline$C D$ & 0.52 & 0.00 & 2.04 & 0.13 & 0.01 & 0.02 & 0.01 & -0.00 & -0.28 & -0.38 & -0.13 & 1.00 & - \\
\hline $\mathrm{RD}$ & 7.78 & 1.59 & 14.21 & 0.03 & 0.05 & 0.05 & 0.05 & 0.02 & -0.18 & 0.15 & 0.86 & 0.05 & 1.00 \\
\hline
\end{tabular}

LOF, liability of foreignness; CSR, corporate social responsibility; TCSR, technology corporate social responsibility; ICSR, Institutional corporate social responsibility; OR, parent organisation reputation; $E D$, economic distance; $C D$, cultural distance; $R D$, regulatory distance.

TABLE 2: Impact of corporate social responsibility and its components on liability of foreignness.

\begin{tabular}{|c|c|c|c|c|c|c|c|c|}
\hline \multirow[t]{2}{*}{ Variable } & \multicolumn{2}{|c|}{ Model 0} & \multicolumn{2}{|c|}{ Model 1} & \multicolumn{2}{|c|}{ Model 2} & \multicolumn{2}{|c|}{ Model 3} \\
\hline & LOF & $Z$-statistics & LOF & $Z$-statistics & LOF & $Z$-statistics & LOF & $Z$-statistics \\
\hline L.LOF & $0.1376 * * *$ & 15.91 & $0.1082 * * *$ & 9.46 & $0.1120 * * *$ & 11.03 & $0.1116 * * *$ & 9.32 \\
\hline CSR & - & - & $-1.446 * * *$ & -6.40 & - & - & - & - \\
\hline TCSR & - & - & - & - & $-1.2663 * * *$ & -9.71 & - & - \\
\hline ICSR & - & - & - & - & - & - & $-1.2400 * * *$ & -8.31 \\
\hline AGE & $0.5708 * * *$ & 7.55 & $0.3407 * * *$ & 2.93 & $0.3918 * * *$ & 3.15 & $0.4025 * * *$ & 3.46 \\
\hline SIZE & $-0.1644 * * *$ & -6.09 & $-0.2140 * * *$ & -7.36 & $-0.2498 * * *$ & -9.04 & $-0.2385 * * *$ & -8.55 \\
\hline ED & $-0.0210 * *$ & -2.21 & 0.0112 & 0.84 & 0.0088 & 0.61 & 0.0012 & 0.09 \\
\hline$C D$ & $1.0309 * * *$ & 3.78 & 0.3562 & 0.78 & 0.4954 & 1.20 & 0.4903 & 1.18 \\
\hline $\mathrm{RD}$ & $0.51459 * * *$ & 3.60 & 0.1756 & 0.94 & 0.0558 & 1.41 & $0.0727^{*}$ & 1.91 \\
\hline Cons & -0.6084 & -1.18 & $6.4799 * * *$ & 5.62 & $3.4557 * * *$ & 4.55 & $2.8907 * * *$ & 3.78 \\
\hline $\operatorname{AR}(1)$ & \multicolumn{2}{|c|}{0.037} & \multicolumn{2}{|c|}{0.022} & \multicolumn{2}{|c|}{0.017} & \multicolumn{2}{|c|}{0.021} \\
\hline$A R(2)$ & \multicolumn{2}{|c|}{0.111} & \multicolumn{2}{|c|}{0.079} & \multicolumn{2}{|c|}{0.084} & \multicolumn{2}{|c|}{0.077} \\
\hline Hansen & \multicolumn{2}{|c|}{0.133} & \multicolumn{2}{|c|}{0.214} & \multicolumn{2}{|c|}{0.179} & \multicolumn{2}{|c|}{0.173} \\
\hline
\end{tabular}

Note: $* * *$, and $* * *$ represent significance levels of $10 \%, 5 \%$, and $1 \%$, respectively. Z-statistics are in parentheses, and $A R(1), \operatorname{AR}(2)$, and Hansen are all p-values.

L.LOF, lagging behind the first-order liability of foreignness; CSR, corporate social responsibility; TCSR, technology corporate social responsibility; ICSR, Institutional corporate social responsibility; $\mathrm{OR}$, parent organisation reputation; $\mathrm{ED}$, economic distance; $\mathrm{CD}$, cultural distance; RD, regulatory distance; $\mathrm{AR}$, Arellano-Bond test.

In Model 1, CSR is significantly negatively correlated with the LOF at the $1 \%$ level, indicating that the fulfilment of CSR helps reduce the LOF faced by enterprises. Therefore, hypothesis 1 is verified.

Model 2 tests the impact of technical CSR on the LOF. According to the results, technical CSR has a significantly negative impact on the LOF at the $1 \%$ level, indicating that enterprises' performance in technical CSR will reduce the LOF. Thus, hypothesis $1 \mathrm{a}$ is supported.

In Model 3, institutional CSR is significantly negatively correlated with the LOF at the $1 \%$ level, and undertaking institutional CSR helps reduce the LOF. Therefore, hypothesis $1 \mathrm{~b}$ is verified. By comparing the results of Models 2 and 3, it can be seen that technical CSR has a greater impact on the LOF, and the effect of implementing technical CSR on reducing the LOF is more significant.

\section{Impact of corporate social responsibility and components on the reputation of the parent company}

Before conducting the mediating effect test, it is necessary to test the influence of independent variables on intermediary variables. Table 3 lists the empirical results of the influence of CSR and its components on the organisational reputation of the parent company. Model 4 contains only control variables. Model 5 shows the overall impact of CSR on the reputation of the parent company. According to the test results in Table 3, there is a significant positive correlation between CSR and the organisational reputation of the parent company at the $1 \%$ level, indicating that the more an enterprise undertakes $\mathrm{SH}$, the better the organisational reputation of the parent company. Hypothesis 2 is, therefore, supported.

Model 6 tests the impact of technical CSR on the organisational reputation of the parent company; it is significantly positively correlated at the $1 \%$ level, supporting the assumption that technical CSR contributes to the improvement of the organisational reputation of the parent company. Hypothesis $2 \mathrm{a}$ is, thus, established.

In Model 7, institutional CSR is also significantly positively correlated with the organisational reputation of the parent company at the $1 \%$ level, and the fulfilment of institutional CSR is conducive to the improvement of the organisational reputation of the parent company. Hypothesis $2 b$ is, thus, verified.

\section{The mediating role of organisational reputation}

Following the method used by Wen et al. (2004), we simultaneously introduce independent and intermediary variables to investigate the significance of their effect on the 
TABLE 3: The impact of corporate social responsibility and its components on corporate reputation of the parent company.

\begin{tabular}{|c|c|c|c|c|c|c|c|c|}
\hline \multirow[t]{2}{*}{ Variable } & \multicolumn{2}{|c|}{ Model 4} & \multicolumn{2}{|c|}{ Model 5} & \multicolumn{2}{|c|}{ Model 6} & \multicolumn{2}{|c|}{ Model 7} \\
\hline & LOF & $Z$-statistics & LOF & $Z$-statistics & LOF & $Z$-statistics & LOF & $Z$-statistics \\
\hline CSR & - & - & $0.1349 * * *$ & 5.42 & - & - & - & - \\
\hline TCSR & - & - & - & - & $0.0679 * * *$ & 4.65 & - & - \\
\hline ICSR & - & - & - & - & - & - & $0.0832 * * *$ & 5.24 \\
\hline AGE & -0.0082 & -0.80 & 0.0008 & 0.08 & -0.004 & -0.04 & 0.0004 & 0.04 \\
\hline SIZE & -0.0046 & -1.29 & -0.0011 & -0.32 & -0.0015 & -0.42 & -0.0011 & -0.30 \\
\hline$C D$ & 0.0217 & 0.71 & 0.0068 & 0.24 & 0.0040 & 0.14 & 0.0073 & 0.25 \\
\hline $\mathrm{RD}$ & $-0.0621 * * *$ & -2.95 & -0.0044 & -0.94 & $-0.0047^{*}$ & -1.01 & -0.0046 & -0.99 \\
\hline Cons & $-0.1366^{* *}$ & -2.41 & $-0.7069 * * *$ & -6.03 & $-0.3100 * * *$ & -4.71 & $-0.3258 * * *$ & -5.02 \\
\hline $\mathrm{Chi}^{2}$ & \multicolumn{2}{|c|}{10.31} & \multicolumn{2}{|c|}{33.67} & \multicolumn{2}{|c|}{25.77} & \multicolumn{2}{|c|}{31.71} \\
\hline$p$ 值 & \multicolumn{2}{|c|}{0.067} & \multicolumn{2}{|c|}{0.000} & \multicolumn{2}{|c|}{0.000} & \multicolumn{2}{|c|}{0.000} \\
\hline
\end{tabular}

Note: $*, * *$, and $* * *$, represent significance levels of $10 \%, 5 \%$, and $1 \%$, respectively. Z-statistics are shown in brackets.

CSR, corporate social responsibility; TCSR, technology corporate social responsibility; ICSR, Institutional corporate social responsibility; OR, parent organisation reputation; ED, economic distance; $\mathrm{CD}$, cultural distance; $\mathrm{RD}$, regulatory distance.

TABLE 4: Test of mediating effect.

\begin{tabular}{|c|c|c|c|c|c|c|}
\hline \multirow[t]{2}{*}{ Variable } & \multicolumn{2}{|c|}{ Model 8} & \multicolumn{2}{|c|}{ Model 9} & \multicolumn{2}{|c|}{ Model 10} \\
\hline & LOF & $Z$-statistics & LOF & $Z$-statistics & LOF & $Z$-statistics \\
\hline L.LOF & $0.1902^{* * *}$ & 40.41 & $0.1912 * * *$ & 41.43 & $0.1919 * * *$ & 45.21 \\
\hline OR & $-3.8458 * * *$ & -22.65 & $-3.8161 * * *$ & -22.80 & $-3.9993 * * *$ & -38.08 \\
\hline CSR & $-0.5778 * * *$ & -17.14 & - & - & - & - \\
\hline TCSR & - & - & $-0.3578 * * *$ & -19.18 & - & - \\
\hline ICSR & - & - & - & - & $-0.3799 * * *$ & -20.57 \\
\hline AGE & $0.7116 * * *$ & 21.18 & $0.7179 * * *$ & 21.46 & $0.6996 * * *$ & 20.47 \\
\hline SIZE & $-0.2223 * * *$ & -18.30 & $-0.2261 * * *$ & -17.51 & $-0.2133 * * *$ & -16.93 \\
\hline ED & $-0.0526 * * *$ & -9.04 & $-0.0513 * * *$ & -8.57 & $-0.0567 * * *$ & -7.82 \\
\hline$C D$ & $1.0051 * * *$ & 11.19 & $1.0177^{* * *}$ & 11.83 & $1.0821 * * *$ & 14.63 \\
\hline $\mathrm{RD}$ & $0.1973 * * *$ & 13.91 & $0.1952^{* * *}$ & 13.91 & $0.2016^{* * *}$ & 12.53 \\
\hline Cons & $0.1911^{* * *}$ & 13.46 & $1.0610^{* * *}$ & 6.09 & $0.8717^{* * *}$ & 5.40 \\
\hline $\mathrm{AR}(1)$ & \multicolumn{2}{|c|}{0.030} & \multicolumn{2}{|c|}{0.029} & \multicolumn{2}{|c|}{0.030} \\
\hline$A R(2)$ & \multicolumn{2}{|c|}{0.092} & \multicolumn{2}{|c|}{0.092} & \multicolumn{2}{|c|}{0.091} \\
\hline
\end{tabular}

Note: $* * *$, and $* * *$, represent significance levels of $10 \%, 5 \%$, and $1 \%$, respectively. Z-statistics are in parentheses, and $\operatorname{AR}(1), \operatorname{AR}(2)$, and Hansen are all $p$-values.

L.LOF, lagging behind the first-order liability of foreignness; CSR, corporate social responsibility; TCSR, technology corporate social responsibility; ICSR, Institutional corporate social responsibility; $\mathrm{OR}$, parent organisation reputation; $\mathrm{ED}$, economic distance; $C D$, cultural distance; RD, regulatory distance; $A R$, Arellano-Bond test.

dependent variables. Generally, after the introduction of mediating variables, if the coefficient of the independent variable is not significant while the mediating variable is significant, the complete mediating effect is considered to exist. If the coefficients of both independent and mediating variables are significant, a partial mediating effect is assumed. For test results refer to Table 4 .

In Table 4, the coefficients of first-order lagged items of LOF in Models 8-10 are significantly positive, suggesting that the LOF has some continuity. The $p$-values of AR(1) in all models are less than 0.05 , of $\mathrm{AR}(2)$ are all greater than 0.05 , and of Hansen are all greater than 0.05 , indicating that the selection of instrumental variables and model settings are reasonable. In Model 8, after the parent company's organisational reputation is also included, both CSR and the parent company's organisational reputation show significant effects on the LOF. Moreover, the degree of CSR influence on the LOF decreases from 1.446 in Model 1 to 0.5778 in Model 8. This indicates that the organisational reputation of the parent company plays a partial mediating role between CSR and LOF. Hypothesis 3 is, therefore, true.
Similarly, in Model 9, after the introduction of mediating variables, both technical CSR and the parent company's organisational reputation still have significant effects on the LOF, and the degree of impact of technical CSR on the LOF decreases from 1.2663 in Model 2 to 0.3578 in Model 9, suggesting that the parent company's organisational reputation plays a partial mediating role. Hypothesis 3a, thus, holds.

In Model 10, institutional CSR and the parent company's organisational reputation have a significant influence on the LOF. The degree of influence of institutional CSR drops from 1.24 in Model 3 to 0.3799 in Model 10. The organisational reputation of the parent company plays a partial mediating role, and therefore Hypothesis $3 b$ holds.

Further comparison shows that the mediating effect of the parent company's organisational reputation on technical CSR and LOF (0.9085) is greater than that for institutional CSR and the LOF (0.8601). This shows that the enterprise's responsibility to the main stakeholders in building the corporate reputation of the parent company has a stronger impact on the LOF. 
TABLE 5: Robustness test.

\begin{tabular}{|c|c|c|c|c|c|c|c|c|c|c|}
\hline \multirow[t]{2}{*}{ Variable } & \multicolumn{2}{|c|}{ Model 11} & \multicolumn{2}{|c|}{ Model 12} & \multicolumn{2}{|c|}{ Model 13} & \multicolumn{2}{|c|}{ Model 14} & \multicolumn{2}{|c|}{ Model 15} \\
\hline & LOF & $Z$-statistics & LOF & $Z$-statistics & LOF & $Z$-statistics & LOF & $Z$-statistics & LOF & $Z$-statistics \\
\hline L.LOF & $0.1915^{* * *}$ & 40.34 & $0.1918^{* * *}$ & 30.39 & $0.1908^{* * *}$ & 41.45 & $0.1915^{* * *}$ & 41.11 & $0.1865^{* * *}$ & 34.01 \\
\hline OR & $-3.9222 * * *$ & -21.54 & $-3.9707 * * *$ & -40.35 & $-3.8048^{* * *}$ & -22.90 & $-3.8402 * * *$ & -22.51 & $-3.5121 * * *$ & -16.32 \\
\hline GD & $-2.3993 * * *$ & -16.03 & - & - & - & - & - & - & - & - \\
\hline YG & - & - & $-0.4021 * * *$ & -13.23 & - & - & - & - & - & - \\
\hline GYS & - & - & - & - & $-0.1796 * * *$ & -19.10 & - & - & - & - \\
\hline SH & - & - & - & - & - & - & - & - & $-0.1437 * *$ & -2.20 \\
\hline AGE & $0.7063^{* * *}$ & 19.99 & $0.7124 * * *$ & 21.28 & $0.7162^{* * *}$ & 21.55 & $0.7210^{* * *}$ & 20.66 & $0.6932 * * *$ & 18.95 \\
\hline SIZE & $-0.2197 * * *$ & -18.60 & $-0.2120 * * *$ & -20.44 & $-0.2252 * * *$ & -17.58 & $-0.2288 * * *$ & -14.02 & $-0.2020 * * *$ & -15.95 \\
\hline ED & $-0.0535 * * *$ & -9.11 & $-0.0586 * * *$ & -9.84 & $-0.0516^{* * *}$ & -8.75 & $-0.0472 * * *$ & -4.70 & $-0.0567 * * *$ & -8.38 \\
\hline$C D$ & $0.9785^{* * *}$ & 9.99 & $1.0613^{* * *}$ & 12.43 & $1.0176^{*}$ & 11.77 & $1.0590 * * *$ & 14.86 & $0.9107^{* * *}$ & 7.52 \\
\hline $\mathrm{RD}$ & $0.1982^{* * *}$ & 13.62 & $0.2063^{* * *}$ & 11.90 & $0.1959 * * *$ & 14.03 & $0.1839 * * *$ & 8.61 & $0.1952^{* * *}$ & 11.87 \\
\hline Cons & $7.6933^{* * *}$ & 17.30 & $0.9327^{* * *}$ & 4.17 & $0.5230 * * *$ & 2.90 & $0.5747^{* * *}$ & 2.72 & $0.5750^{* * *}$ & 2.65 \\
\hline $\operatorname{AR}(2)$ & \multicolumn{2}{|c|}{0.093} & \multicolumn{2}{|c|}{0.091} & \multicolumn{2}{|c|}{0.092} & \multicolumn{2}{|c|}{0.092} & \multicolumn{2}{|c|}{0.094} \\
\hline Hansen & \multicolumn{2}{|c|}{0.359} & \multicolumn{2}{|c|}{0.299} & \multicolumn{2}{|c|}{0.352} & \multicolumn{2}{|c|}{0.331} & \multicolumn{2}{|c|}{0.444} \\
\hline
\end{tabular}

Note: $* * *$ and $* * *$, represent the significance level of $10 \%, 5 \%$ and $1 \%$, respectively. Z-statistic is in parentheses, and $A R(1), \operatorname{AR}(2)$, and Hansen are all $p$-values.

L.LOF, lagging behind the first-order liability of foreignness; TCSR, technology corporate social responsibility; ICSR, Institutional corporate social responsibility; OR, parent organisation reputation; $\mathrm{ED}$, economic distance; $\mathrm{CD}$, cultural distance; RD, regulatory distance; AR, Arellano-Bond test; GD, shareholder responsibility; YG, employee responsibility; GYS, supplier, customer, and consumer rights responsibility; $\mathrm{HJ}$, environmental responsibility; $\mathrm{SH}$, social responsibility.

\section{Robustness test}

To verify the reliability of the empirical results, this article divides CSR into shareholder responsibility (GD), employee responsibility (YG), supplier, customer, and consumer rights responsibility (GYS), environmental responsibility $(\mathrm{HJ})$, and social responsibility ( $\mathrm{SH}$ ) according to the HeXun scoring system. The impact of the five subdivided dimensions on the LOF and the mediating effect of the parent company's organisational reputation are examined. The results of the analysis are shown in Table 5.

In Table 5, the first-order lag term of LOF is significantly positive. The $p$-values of $\mathrm{AR}(1)$ in all models are less than 0.05 , the $p$-values of $\mathrm{AR}(2)$ are all greater than 0.05 , and the $p$-values of Hansen are all greater than 0.05 , indicating that the model meets the requirements of instrumental variables and is set reasonably. After the introduction of mediating variables, the impact of the five subdivided dimensions of CSR and the parent company's organisational reputation on LOF remains significant. This indicates that part of the mediating effect is established, which is consistent with the original test results, thus verifying their stability and veracity.

\section{Conclusion}

\section{Theoretical significance}

From the perspective of non-market mechanisms, this study elaborates on the impact of CSR and its components on LOF and the mediating effect of the parent company's organisational reputation. The following conclusions are drawn:

First, fulfilling CSR is negatively correlated with the LOF. Therefore, the fulfilment of CSR can help reduce LOF; thus, hypothesis 1 has been verified. The result is consistent with the conclusion of Mithani (2017), who considered that philanthropy could mitigate the LOF after a national disaster. Both technical and institutional CSR have a significant negative impact on LOF; thus, hypotheses $1 \mathrm{a}$ and $1 \mathrm{~b}$ are true. At the same time, the impact of technical CSR on LOF is greater than that of institutional CSR.

Secondly, there is a significant positive correlation between CSR and the reputation of the parent organisation; thus, hypothesis 2 is established. Both technical and institutional CSR have a positive impact on the reputation of the parent organisation, supporting hypotheses $2 \mathrm{a}$ and $2 \mathrm{~b}$. The result is similar to Zhou and Wang (2020); according to them, high subsidiary CSR activities help subsidiaries gain legitimacy and reduce the reputation risk of the parent firm.

Finally, the reputation of the parent organisation partially mediates the relationship between CSR and LOF. Hypothesis 3 is thus established. After adding the mediate variables, the impact of technical and institutional CSR on LOF is reduced, and the reputation of the parent organisation is considered to play a partial mediating role. Thus, hypotheses $3 \mathrm{a}$ and $3 \mathrm{~b}$ are supported. Moreover, the mediating effect of the organisational reputation of the parent company on technical CSR and LOF is greater than that on institutional CSR and LOF.

\section{Practical implication}

Based on the above theoretical analysis, enterprise managers should pay attention to the following aspects:

First, fulfilling social responsibilities helps the subsidiary reduce its LOF. In the process of fulfilling SRSH, it is inevitable for MNCs to communicate and coordinate with other stakeholders to foster increased mutual understanding. By actively assuming social responsibilities, MNCs can establish good government-enterprise relations and aid local economic development and employment, thus obtaining support or preferential policies from local governments; this is conducive to reducing the LOF. Transnational corporations 
actively undertake responsibilities with partners, including suppliers and consumers, which attract consumers to buy their products, while also attracting high-quality suppliers to participate, thus improving corporate performance and reducing the LOF that they may encounter. Multinational corporations actively assume their responsibilities towards employees and can provide them with a reasonable working platform and development opportunities, which is conducive to cultivating employees' sense of identity, stimulating their creativity, and enhancing corporate cohesion, thereby reducing the LOF faced by MNCs.

Second, both technical and institutional CSR can reduce LOF, but the effect of technical CSR is more significant. Enterprises undertake technical CSR for major stakeholders, regarded as an exchange within the stakeholder network, which can provide guarantees for the actual operational activities of enterprises and reduce the impact of LOF. In meeting their responsibility towards shareholders, enterprises actively carry out business activities to expand production and increase earnings. In meeting their responsibility to employees, they strive to create a positive working environment while providing learning opportunities and development platforms for employees to constantly improve themselves. Taking responsibility for the supply chain can further optimise the relationship between upstream and downstream stakeholders and ensure smooth operations. Enterprises pursuing institutional CSR for secondary stakeholders undertake voluntary social behaviours based on realistic demands, making it easier to win favour, enhance legitimacy, and ultimately, reduce their LOF.

Third, focus on building the reputation of the parent organisation. Enterprises carry social responsibilities for their major stakeholders, which is conducive to improving their production efficiency. Contributions to local economic development and employee employment will receive unanimous praise from all sides and establish a good reputation, thus attracting more qualified employees to participate, helping the enterprise to grow and develop. A virtuous circle is thus formed. Corporate environmental responsibility helps alleviate local environmental problems and build a responsible corporate image and reputation of the parent company. When an enterprise undertakes its charitable responsibility and assists stakeholders in overcoming their difficulties, it will be recognised by the local society, thereby enhancing its organisational reputation.

Fourth, enterprises can also enhance the reputation of their parent companies and overcome LOF by fulfilling social responsibilities. In addition to directly affecting the LOF, CSR may also have an indirect impact by establishing the reputation of the parent company. An enterprise that is courageous and effective in assuming social responsibilities will garner a positive reputation among its stakeholders. A positive organisational reputation and public praise can attract stable customer groups and encourage greater customer loyalty towards an enterprise, assisting the formation of core competitiveness, and reducing the influence of the enterprise's LOF.

\section{Limitation and future areas of study}

Although this study explores the impact of CSR on LOF from the perspective of non-market mechanisms by introducing the parent company's organisational reputation variable to further explore the possible mechanism between them, areas that need further improvement remain. First, there is an opportunity to further verify the general applicability of these research findings and conclusions by selecting samples from within the manufacturing or other service industries. Second, this study concludes that the parent company's organisational reputation plays a partial mediating role in the relationship between CSR and the LOF. Thus, future studies can further explore the influence of other mediating variables to establish whether they exert a moderating effect on the specific mediating effect. Finally, this study primarily uses HeXun data in the data selection and measurement of CSR, whereas future studies should try to verify the results by using data from questionnaires and other sources.

\section{Acknowledgements Competing interests}

The authors declare that they have no financial or personal relationships that may have inappropriately influenced them in writing this article.

\section{Authors' contributions}

Y.Z. and Y.J. conceived of the presented idea. Z.Y. developed the theory and performed the computations. J.Y. verified the analytical methods. Both the authors discussed the results and contributed to the final manuscript.

\section{Ethical considerations}

This article followed all ethical standards for carrying out research without direct contact with human or animal subjects.

\section{Funding information}

This work was supported by the National Social Science Foundation of China [grant number 19BGL024].

\section{Data availability}

The data that support the findings of this study are available from the corresponding author (Y.J.), upon reasonable request.

\section{Disclaimer}

The views and opinions expressed in this article are those of the author and do not necessarily reflect the official policy or position of any affiliated agency of the author or their institutions.

\section{References}

Barnett, M.L., Jermier J.M., \& Lafferty, B.A. (2006). Corporate reputation: The definitional landscape. Corporate Reputation Review, 9(1):26-38. https://doi. org/10.1057/palgrave.crr.1540255 
Bauer, R., Derwall, J., \& Hann, D. (2009). Employee relatons and credit risk. Working Paper. https://dx.doi.org/10.2139/ssrn.1483112.

Benlemlih, M., \& Girerd-Potn, I. (2014). Does corporate social responsibility affectfirm financial risk? Evidence from internatonal data. Working Paper. Financial Management Association European Conference (FMA), Maastricht (The Netherlands).

Bhattacharya, C.B., \& Sen, S. (2004). Doing better at doing good: When, why, and how consumers respond to corporate social initiatives. California Management Review, 47(1), 9-24. https://doi.org/10.2307/41166284

Bouslah, K., Kryzanowski, L., \& M'Zali, B. (2013). The impact of the dimensions of social performance on firm risk. Journal of Banking \& Finance, 37(4), 1258-1273. https://doi.org/10.1016/j.jbankfin.2012.12.004

Brammer, S., \& Pavelin, S. (2004). Building an good reputation. European Managemen Journal, 22(6), 704-713. https://doi.org/10.1016/j.emj.2004.09.033

Cai, L., Cui, J., \& Jo, H. (2016). Corporate environmental responsibility and firm risk. Journal of Business Ethics, 139(3), 563-594. https://doi.org/10.1007/s10551 015-2630-4

Campbell, J.T., Eden, L., \& Miller, S.R. (2012). Multinationals and corporate social responsibility in host countries: Does distance matter? Journal of Inter
Business Studies, 43(1), 84-106. https://doi.org/10.1057/jibs.2011.45

Carroll, A.B. (1991). The pyramid of corporate social responsibility: Toward the moral management of organizational stakeholders. Business Horizons, 34(4), 39-48. https://doi.org/10.1016/0007-6813(91)90005-G

Cheng, B., loannou, I., \& Serafeim, G. (2014). Corporate social responsibility and access to finance. Strategic Management Journal, 35(1), 1-23. https://doi. access to finance. Strat
org/10.1002/smj.2131

Chen, H., Griffith, D.A., \& Hu, M.Y. (2006). The influence of liability of foreignness on market entry strategies, an illustration of market entry in China. International

Doh, J.P., Howton, S.D., Howton, S.W., \& Siegel, D.S. (2009). Does the market respond to endorsement of social responsibility? The role of institutions, information, and legitimacy. Journal of Management, 36(1), 1461-1485. https:// doi.org/10.1177/0149206309337896

Du, X.J., Shi, Y.H., \& Cai, L.S. (2016). A study on liability of foreignness in stock market. Management Science, 30(5), 148-160.

Eberle, D., \& Li, T. (2013). The impact of interactive corporate social responsibility communication on corporate reputation. Journal of Business Ethics, 118(4), 731-746. https://doi.org/10.1007/s10551-013-1957-y

Eden, L., \& Miller, S.R. (2004). Distance matters: Liability of foreignness, institutional distance and ownership strategy. Advances in International Management, 16(3) 29(04)16010-1

Entine, J. (2003). The myth of social investing: A critique of its practice and consequences for corporate social performance research. Organization Environment, 16(8), 352368. https://doi.org/10.1177/1086026603256283

Freeman, R.E., Harrison, J.S., \& Wicks, A.C. (2008). Managing for stakeholders: Survival, reputation, and success. New Haven, CT: Yale University Press.

Godfrey, P.C. (2005). The relationship between corporate philanthropy and shareholder wealth: A risk management perspective. The Academy of Management Review, wealth: A risk management perspective. The Academy of $M$
30(4), 777-798. https://doi.org/10.5465/amr.2005.18378878

Godfrey, P.C., Merrill, C.B., \& Hansen, J.M. (2009). The relationship between corporate social responsibility and shareholder value: An empirical test of the risk management hypothesis. Strategic Management Journal, 30(4), 425-445. https://doi.org/10.1002/smj.750

Gomes, R.M., Carneiro, J., \& Dib, L.A. (2018). Branded retailer expansion on a continent-sized emerging market. International Journal of Retail \& Distributio Management, 46(9), 820-834. https://doi.org/10.1108/IJRDM-10-2017-0258

Hasseldine, J., Salama, A.I., \& Toms, J.S. (2005). Quantity versus quality: The impact of environmental disclosures on the reputations of UK plcs. British Accounting Review, 37(2), 231-248. https://doi.org/10.1016/j.bar.2004.10.003

Huang, J., Duan, Z.X., \& Zhu, G.W. (2017). Does corporate social responsibility affect the cost of bank loans? Evidence from China. Emerging Markets Finance \& Trade, 53(7), 1589-1602. https://doi.org/10.1080/1540496X.2016.1179184

Huo, B., \& Zhou, Y.H. (2014). The relationship between corporate social responsibility, corporate reputation and corporate performance. Industrial Technical Economy, $32(1), 59-65$.

Klossek, A., Linke, B.M., \& Nippa, M. (2012). Chinese enterprises in Germany: Establishment modes and strategies to mitigate the liability of foreignness. Journal of World Business, 47(1), 35-44. https://doi.org/10.1016/j.jwb.2010.10.018

Kogut, B., \& Singh, H. (1988). The effect of national culture on the choice of entry mode. Journal of International Business Studies, 19(3), 411-432. https://doi org/10.1057/palgrave.jibs.8490394

Kostova, T. (1997). Country institutional profiles: Concept and measurement. Academy of Management Proceedings, 8(1), 180-186. https://doi.org/10.5465/ambpp 1997.4981338

Kostiva, T., \& Zaheer, S. (1999). Organizational legitimacy under conditions of Review, 24(1), 64-81. https://doi.org/10.5465/amr.1999.1580441

Kuo, L., \& Chen, Y.J. (2013). Is environmental disclosure an effective strategy on establishment of environmental legitimacy for organization? Managemen Decision, 51(7), 1462-1487. https://doi.org/10.1108/MD-06-2012-0395

Lai, C.S., Chiu, C.J., Yang, C.F., \& Pai, D.C. (2010). The effects of corporate social responsibility on brand performance: The mediating effect of industrial brand equity and corporate reputation. Journal
https://doi.org/10.1007/s10551-010-0433-1

Li, H.Q., \& Zhang, Z.G. (2010). An empirical study on the influence of CSR on corporate reputation and customer loyalty. Nankai Management Review, 13(1), 90-98.

Madhok, A., \& Keyhani, M. (2012). Acquisitions as entrepreneurship: Asymmetries, opportunities, and the internationalization of multinationals from emerging
economies. Global Strategy Journal, 2(1), 26-40. https://doi.org/10.1002/gsj.1023
Maignon, I., \& Ferrell, O.C. (2004). Corporate social responsibility and marketing: An integrative framework. Journal of the Academy of Marketing Science, 10(1), 3-19. https://doi.org/10.1177/0092070303258971

María, D.O., \& Elisa, B.D. (2017). Is corporate reputation associated with quality of CSR reporting? Evidence from Spain. Corporate Social Responsibility \& Environmental Management, 24(2), 121-132. https://doi.org/10.1002/csr.1399

Marano, V., Tashman, P., \& Kostova, T. (2017). Escaping the iron cage: Liabilities of origin and CSR reporting of emerging market multinational enterprises. Journal of
International Business Studies, 48(3), 386-408. https://doi.org/10.1057/jibs.2016.17

Mattingly, J.E., \& Berman, S. (2006). Measurement of corporate social action: Discovering taxonomy in the Kinder Lydenburg domini ratings data. Business \& Discovering taxonomy in the Kinder Lydenburg domini ratings data.
Society, 45(1), 20-46. https://doi.org/10.1177/0007650305281939

Melo, T., \& Garrido-Morgado, A. (2012). Corporate reputation: A combination of socia responsibility and industry. Corporate Social Responsibility \&Environmental Management, 19(1), 11-31. https://doi.org/10.1002/csr.260

Mitchell, G.E. (2015). The attributes of effective NGOs and the leadership values associated with a reputation for organizational effectiveness. Nonprofit Management \& Leadership, 26(1), 39-57. https://doi.org/10.1002/nml.21143

Mithani, M.A. (2017). Liability of foreignness, natural disasters, and corporate philanthropy. Journal of International Business Studies, 48(1), 941-963. https:// philanthropy. Journal of Internation-x
doi.org/10.1057/s41267-017-0104-x

Mitra, R. (2011). Framing the corporate responsibility-reputation linkage: The case of Tata motors in India. Public Relations Review, 37(4), 392-398. https://doi. org/10.1016/j. pubrev.2011.06.002

Mo, S.J., \& Wang, C.M. (2012). Research and prospect of organizational reputation from the perspective of behavioral cognition. Foreign Economies and Management, $34(3), 65-71$.

Nachum, L. (2003). Liability of foreignness in global competition? Financial service affiliates in the city of London. Strategic Management Journal, 24(12), 1187-1208. affiliates in the city of London. Stratt
https://doi.org/10.1002/smj.347

Neville, B.A., Bell, S.J., \& Menguc, B. (2005). Corporate reputation, stakeholders and the social performance-financial performance relationship. European Journal of Marketing, 39(9/10), 1184-1198. https://doi.org/10.1108/03090560510610798

Odriozola, M.D., \& Baraibar-Diez, E. (2017). Is corporate reputation associated with quality of CSR reporting? Evidence from Spain. Corporate Social Responsibility and Environmental Management, 24(2), 121-132. https://doi.org/10.1002/csr.1399

Padanyi, P., \& Gainer, B. (2003). Peer reputation in the nonprofit sector: Its role in nonprofit sector management. Corporate Reputation Review, 6(3), 252-265. nonprofit sector management. Corporate Repu
https://doi.org/10.1057/palgrave.cr.1540204

Pant, A., \& Ramachandran, J. (2017). Navigating identity duality in multinational subsidiaries: A paradox lens on identity claims at Hindustan Unilever 1959-2015. Journal of International Business Studies, 48(4), 664-692. https://doi.org/10.1057/ s41267-017-0076-x

Peloza, J., \& Shang, J. (2011). How can corporate social responsibility activities create value for stakeholders? A systematic review. Journal of the Academy of Marketing Science, 39(1), 117-135. https://doi.org/10.1007/s11747-010-0213-6

Petersen, B., \& Pedersen, T. (2002). Coping with liability of foreignness: Different leaning engagements of entrant firms. Journal of International Management, leaning engagements of entrant firms. Journal of Internationa
$8(3), 339-350$. https://doi.org/10.1016/S1075-4253(02)00068-6

Porter, M.E. (2006). Strategy \& society: The link between competitive advantage and corporate social responsibility. Harvard Business Review, 84(12), 78-92.

Salomon, R., \& Wu, Z. (2012). Institutional distance and local isomorphism Strategy. Journal of International Business Studies, 43(4), 343-367. https://doi. org/10.1057/jibs.2012.3

Verwijmeren, P., \& Derwall, J. (2010). Employee well-being, firm leverage, and bankruptcy risk. Journal of Banking \& Finance, 34(5), 956-964. https://doi. bankruptcy risk. Journal of Banking
org/10.1016/j.jbankfin.2009.10.006

Wang, R., Tian, Z.L., \& Yang, W. (2012). Group segmentation and influence mechanism of consumer CSR response in Chinese context. Business Review, 24(8), 107-117.

Wen, S.B., \& Fang, Y. (2008). An empirical study on the relationship between corporate social Responsibility and financial performance: Panel data analysis from the perspective of stakeholders. China Industrial Economics, 25(10), 150-160.

Wen, Z.L., Zhang, L., Hou, J.T., \& Liu, H.Y. (2004). The procedure of mediating effect test and its application. Journal of Psychology, 49(5), 614-620.

Williams, R.J., \& Barrett, J.D. (2000). Corporate philanthropy, criminal, activity, and firm reputation: Is there a link? Journal of Business Ethics, 26(4), 341-350. https:// doi.org/10.1023/A:1006282312238

Yoon, Y., Gurhan-Canli, Z., \& Schwarz, N. (2006). The effect of corporate social responsibility activities on companies with bad reputations. Journal of Consumer Psychology, 16(4), 377-390.

Yuan, L. (2019). Institutional distance and OFDI entry mode selection of Chinese enterprises: A data test based on listed enterprises. Economy and Management, 33(6), 86-92.

Zaheer, S. (1995). Overcoming the liability of foreignness. Academy of Management Journal, 38(2), 341-363. https://doi.org/10.2307/256683

Zeng, Z.X., Zhang, C.C., \& Wang, M.Y. (2017). Corporate social responsibility performance, reporting quality and corporate reputations: An empirical study of Chinese listed companies. Industrial Technical Economy, 36(6), 87-95.

Zhang, Y.T., \& Wang, Z.T. (2015). The effect of institutional distance on liability of foreignness: The moderating role of imitative isomorphism. Contemporary foreignness: The moderating role of
Finance \& Economics, 365(4), 97-106.

Zhang, Y.T., Wang, Z.T., \& Jiang, Y.L. (2016). The impact of regional economic agglomeration on the liability of foreignness: An analysis based on 500 multinational subsidiaries in China. Journal of International Trade, 42(7), 109-118.

Zhou, N., \& Wang, H.L. (2020). Foreign subsidiary CSR as a buffer against parent firm reputation risk. Journal of International Business Studies, 51(15), 1256-1282. https://doi.org/10.1057/s41267-020-00345-7 